\title{
AGRICULTURAL DEVELOPMENTS
}

\author{
IN \\ AFGHANISTAN
}

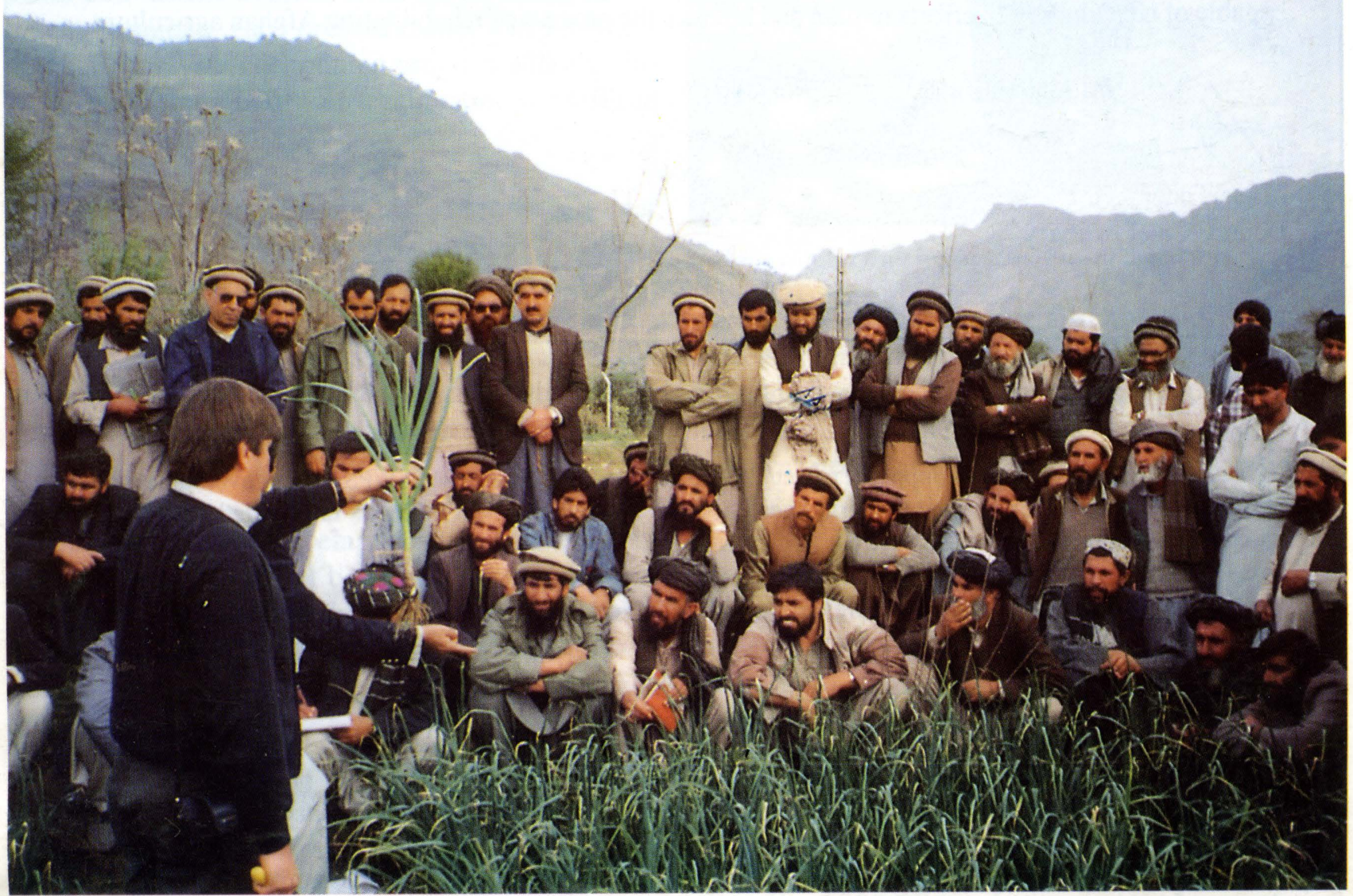

Inside this issue: Human Resource Development 
ASSP/PSA's work of supplying agricultural inputs, conducting demonstrations and field trials, and surveying must come to a halt with the seasonal onset of bad weather in Afghanistan. With the coming of winter, our attention shifts from these field activities to the task of continuing to build human resources. Each year we use the winter months to equip our extension agents and survey staff with the latest knowledge and techniques. This knowledge will increase their effectiveness in the field and their ability to pass on what they learn to others. This year is exceptional only in the numbers of people we will train and our use of primarily local resources.

ASSP/PSA once again plans to give training in the agricultural sciences to more people in order to prepare them to work with Afghan farmers. Our ADT component continues to increase the number of participants and at the same time expand the curriculum. We are building upon the excellent cooperation received in past years from Pakistani agricultural and training institutions. The object is to institutionalize these ties between the two countries allowing Afghan agrizulturalists to benefit from the considerable and readily transferrable expertise and experience developed by Pakistan over the past decade.

Our training of surveyors, analysts and geographic information systems technicians has begun to bear fruit. ASSP/PSA now has an experienced team of professionals capable of providing critical information that is both accurate and timely regarding basic agricultural statistics for policy and program decision making. Training now underway seeks to increase the number of Afghan professionals capable of contributing to efforts to plan and manage the process of rehabilitating Afghan agriculture

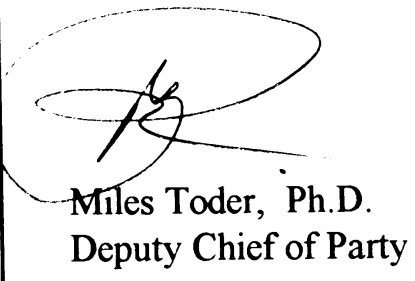

Cover: Vegetable training and demonstration in the field.

The Afghanistan Agriculture Sector Support Project/Private Sector Agribusiness (ASSP/PSA) is a development assistance program implemented by Development Alternatives, Inc. and funded by the Office of the United States Agency for International Development, Representative for Afghanistan.

ASSP/PSA focuses efforts in two areas of Afghan agricultural development. It provides technical training for farmers in Afghanistan to increase food production and it gathers, analyzes and disseminates information about agricultural markets and production.

Agricultural Developments in Afghanistan is a publication of Development Alternatives, Inc., Agricultural Sector Support Project/Private Sector Agribusiness (ASSP/PSA). The views and interpretations presented are those of the individual authors and do not reflect those of the office of USAID, Representative for Afghanistan.

Reproduction of the contents is permitted with an acknowledgment of the source. Comments are solicited and encouraged from donor and implementing organizations concerned with agricultural development in Afghanistan.

All correspondence concerning Agricultural Developments in Afghanistan should be addressed to the Editor, ASSP/PSA, P.O.Box 2721, Islamabad, Pakistan. Telephone: 051-214781-4. Fax: 051-214785

Editor: Fran Swift; Contributors: Miles Toder, Khairullah Dawlaty, Asif Niazi, Temur Aziz.

Desktop Publishing Technicians: Hafizullah, Fatima Sediq and Hashim Ali. 


\section{TRAINING, TRAINING, TRAINING: Spreading Knowledge of Agriculture Technology}

From October 3 - 8, 1992 Leighton Smith (See Agricultural Developments in Afghanistan, Issue 5, page 5.) will conduct a workshop in viticulture as part of a post harvest training program for Agricultural Development and Training (ADT) extension workers. Mercy Corps International (MCI), another non-governmental organization, will be a co-sponsor. This training program marks a first - it will be held across the border in Kandahar as well as in Quetta!

Also during the month of October and into mid-November a mobile training program will be held in Aghanistan for new orchard growers. ASSP/PSA staff have assisted in the establishment of approximately 1700 new orchards since the current progam began in 1989. A two-day training program has been designed to instruct these new orchard owners in proper methods of insect and disease control. After participating in the training program, each orchard owner will receive a backpack sprayer. The training program will also include demonstrations of proper calibration and safe use of the sprayers.

Next on the ADT training agenda is the annual winter training program. This year it is being expanded to include Afghan agriculturalists who have not had access in recent years to training and demonstration programs. Because of the increased number and background of the participants, the program will start in Peshawar in November, a month earlier than in past years.

Training participants are being sought particularly from areas where ADT has not been working, from important wheat growing areas, from areas which are readily accessible, and from areas where other non-governmental organizations (NGOs) are active. Individual selection is based on the recommendations made by NGOs and local shuras. All candidates must be working in agriculture at present and demonstrate their intention to continue to do so. Final approval will be made by ADT staff.

During the three year period from August 1989 through August 1992 the ADT component of ASSP/PSA has conducted 26 training programs totalling more than

\section{7,500 man days of training.}

In 1990 two programs dealt with orientation, management and project implementation. In 1991 five programs

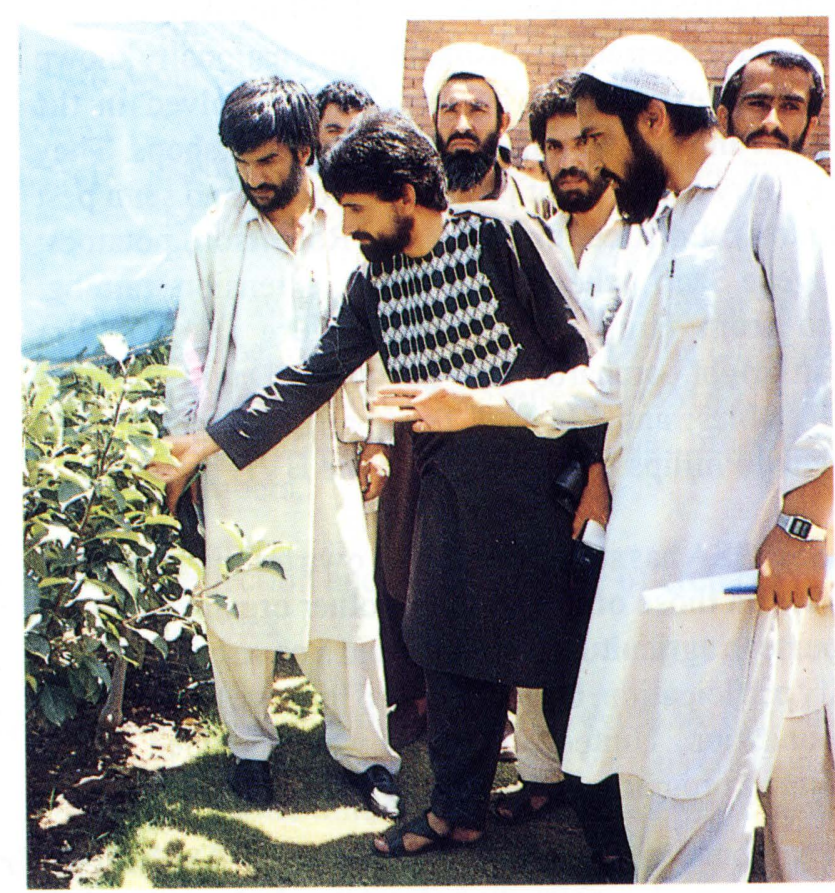

Students check a fruit tree in a nursery in Swat.

were devoted to training administrative staff in various aspects of office administration and management. Two programs were devoted to program evaluation. The remaining 17 training programs have focused on the technical needs of the field staff of ADT and other NGOs.

Members of the ADT field staffare primarily extension agents. They regularly attend training workshops given by ADT in Quetta or Peshawar and then return to their home communities in Afghanistan to share their learning and monitor progress on extension activities.

As many as two dozen ADT field staff members are machinery operators. They regularly receive training in Pakistan to operate and maintain the machinery purchased by ASSP/PSA and transported to demonstration farms in Afghanistan. Machinery includes: self-powered threshers, reapers, corn shellers, sprayers and tractors with a wide assortment of tractor attachments. 


\section{Spreading Knowledge continued...}

The size of the training program has grown steadily during the life of the project. In December 1991 a total of 110 persons attended field staff training, more than double the number of participants (43) in 1990. Numbers are expected to increase again this year by at least $100 \%$.

In the two years between August 1990 and August 1992 there have been eight consultants, internationally known for their expertise, who have been involved in the design and conduct of ADT training workshops. They are: Jerry Rand, plant protection (locust and senn pest control); Ed Rice, maize; Garry Robertson, potatoes; Eugene Saari, wheat; John Conje, extension training; and from High Value Horticulture (HVH): Jim Cartwright, orchards and nurseries; David Parsons, vegetables; and Michael Tsamparlis, apricot drying. Denzil Phillips has coordinated the HVH activities.

ASSP/PSA has supplemented its own training capabilities with those offered through other organizations. A course in agricultural statistics and a course in community participation, both sponsored by Save the Children

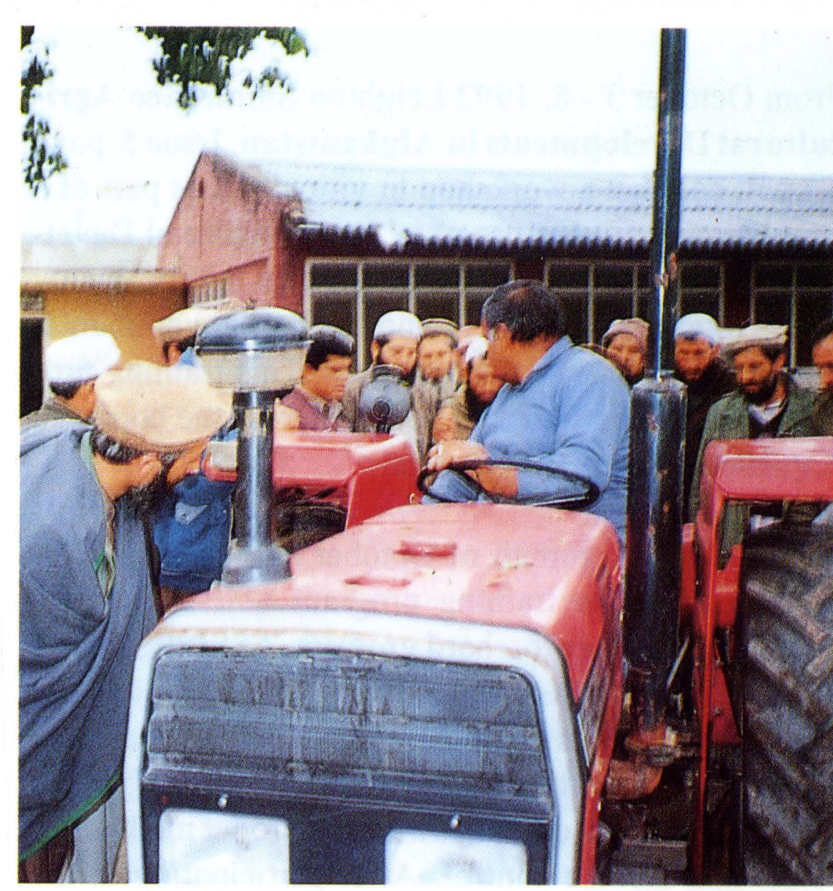

ADT winter training includes instruction in operation of farm machinery.

Foundation, United Kingdom, were included in the training programs of December 1990 and July 1991.

\section{ADT Technical Training Schedule*}

\begin{tabular}{|c|c|c|c|}
\hline$\overline{\text { Date }}$ & Description & $\begin{array}{c}\text { Duration } \\
\text { (days) }\end{array}$ & $\begin{array}{c}\text { No. of } \\
\text { Participants }\end{array}$ \\
\hline Aug. '89 & Field Staff Training & 14 & 25 \\
\hline May. '90 & Wheat Thresher Operation & 21 & 17 \\
\hline May. '90 & Tractor Operation & 21 & 14 \\
\hline Aug. ' 90 & Locust \& Senn Pest & 60 & 22 \\
\hline Dec. ' 90 & Field Staff Training & 75 & 43 \\
\hline Dec. ' 90 & Nursery Operation & 45 & 8 \\
\hline May. '91 & Tractor \& Thresher Operation & 30 & 12 \\
\hline Jun. '91 & Apricot Drying & 30 & 29 \\
\hline Jul. ' '91 & Extension Program Orientation & 28 & 19 \\
\hline Oct. '91 & Community Participation & 5 & 15 \\
\hline Dec. '91 & Field Staff Training & 70 & 110 \\
\hline Jan. ' '92 & Machinery Staff Training & 45 & 26 \\
\hline May. '92 & Apricot Drying I & 5 & 22 \\
\hline Jun. ' '92 & Apricot Drying II & 7 & 34 \\
\hline Jul. ' '92 & Nursery Operation & 6 & 13 \\
\hline Aug. ' '92 & Vegetable Production I & 6 & 13 \\
\hline Aug. ' '92 & Vegetable Production II & 6 & 24 \\
\hline
\end{tabular}

* Most persons participated in more than one training program. 


\section{TRAINING, TRAINING, TRAINING : Training the Eyes and Ears of ASSP/PSA}

In September 1992 there were 33 surveyors working in the Agricultural Statistics Unit of the Program Planning and Analysis (PPA) component of the Agricultural Sector Support Project/Private Seetor Agribusiness (ASSP/PSA). The surveyors are primarily responsible for the collection of data on crop yields, commodity prices, land use, availability of agricultural inputs, farmer cultural practices and problems facing Afghan farmers. This information is collected by a variety of methods including measurements based upon direct observation and respondent interviews.

The survey methodology commonly used involves sending the surveyors to collect data from randomly selected points in specifically targeted provinces. The surveyors also ground truth the data received through satellite imagery. Other surveyors collect market price information.

Keeping in mind the survey methodology and the field data requirements, a training program has been developed to make the surveyors proficient in the use of instruments such as the global positioning system (GPS) and the compass, improve their map reading ability, and enhance their data collection skills. Another vital part of training is development of the surveyors'confidence in their ability to handle themselves in any emergency situations which may arise during cross border surveys.

Carrying out surveys in Afghanistan is made particularly difficult because of civil strife, lack of security and damage done to the communications networks during the 14 year occupation. Other difficulties result from the fact that many parts of Afghanistan were not connected by roads even before the war. The nonavailability of accurate and up-to-date maps further complicates the task. To perform well under these conditions the PPA surveyors require specialized training and skills which are not necessary for surveyors in most parts of the world.

The surveyor training program includes the following courses:

1. Intensive GPS training with regular refresher courses
2. Map reading and compass use with refresher courses

3. English language with emphasis on report writing - This course is continuous and is conducted whenever the surveyors are not busy carrying out surveys.

4. Basic math with emphasis on keeping proper accounts in the field

5. Mine awareness - This course is given to one member of each survey team by the Organization for Mine Awareness (OMA).These courseparticipants later train the other team members.

6. Collection and proper storage of crop cut samples

During the training program the surveyors are regularly evaluated to assess the impact of the various courses on their skills. Other training includes pre-survey orientation of the survey methodology and the handling of emergencies and unexpected situations. Lectures, role playing and field trips are involved in this training.

Several of the surveyors have attended courses for ASSP/PSA agricultural extension agents run by ADT with the assistance of other agencies and consultants. These courses include: identification of crop diseases,

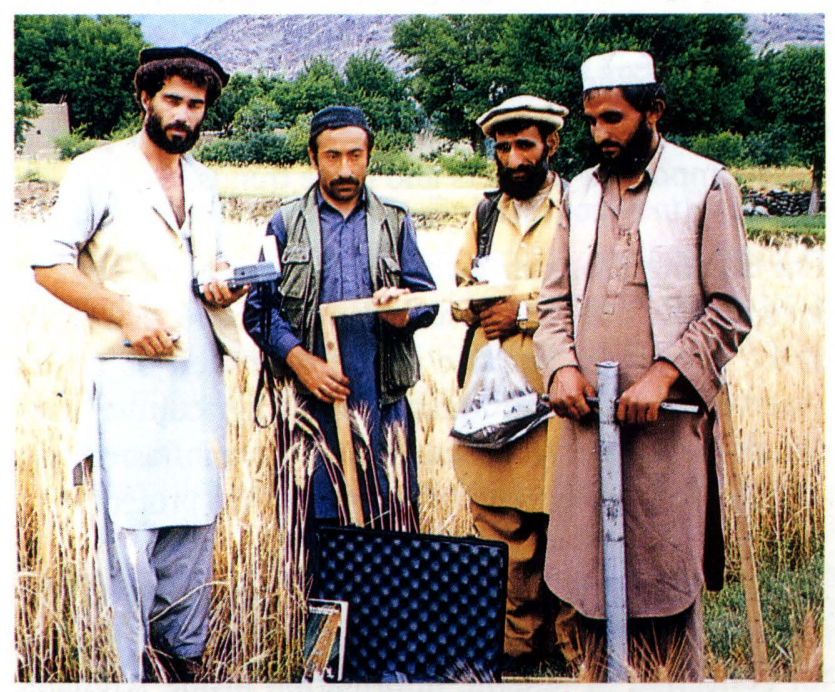

A survey team prepares to take field measurements. 


\section{TRAINING, TRAINING, TRAINING : \\ Putting It All Together}

Members of the Information Unit (IU) of the Program Planning and Analysis (PPA) component of ASSP/PSA both give and receive training frequently. They must keep up with office demands and new automation products.

Since the Information Unit, as now constituted, came into being in the third quarter of 1991, Geographic Information System (GIS) technicians have received

\section{Training Eyes and Ears cont....}

water and fertilizer requirements, horticulture, vegetables, the use of farm machinery, techniques of interviewing farmers, survey sampling and agricultural statistics.

The market information system (MARIS) data collectors require special training in how to:

- conduct interviews,

- identify reliable sources of information,

- explain clearly the type and quality of commodities for which data are needed,

- analyze for accuracy the replies of persons interviewed, and

- discover the reasons for price fluctuations in the market.

Training for MARIS data collectors has been designed and given by PPA staff with extensive knowledge of market conditions in Afghanistan, the various types and qualities of commodities available, consumer preferences, important markets and price trends.

The training program for the final quarter of 1992 is designed not only to improve the data collection skills of the surveyors, but also to improve their ability to observe and record information about agricultural conditions in Afghanistan, damage done to the infrastructure and socioeconomic data of interest to the project.

As a result of the extensive training given to the surveyors, PPA has developed a substantial capacity for collection of reliable information inside Afghanistan. nearly 300 hours of in-house training. Courses have been given in ARC/INFO, Capture, Atlas and dBase IV, software programs particularly important to the GIS function. The Atlas training was given by a consultant from Peshawar. The director of IU received two weeks of intensive training in GIS in the USA. Three IU staff members received advanced training in the use of printers and plotters.

IU staff, and consultants brought in by IU, provide staff from other ASSP/PSA offices with on-the-job training and short courses needed in the new and sophisticated computer software used by ASSP/PSA. Refresher courses are also given as necessary.

Among those trained have been accountants, administrative assistants, administrators, economists, market information system (MARIS) analysts, monitors, secretaries and surveyors. Training given has been in DOS, Word Perfect 5.1, Lotus, dBase III+, dBase IV and Harvard Graphics. Members of the publications staff have received specialized training in Aldus Pagemaker, Microsoft Windows and, in anticipation of publications in Dari, a Dari word processing program. Training is provided for staff in the Peshawar and Quetta offices of ASSP/PSA as well as in Islamabad.

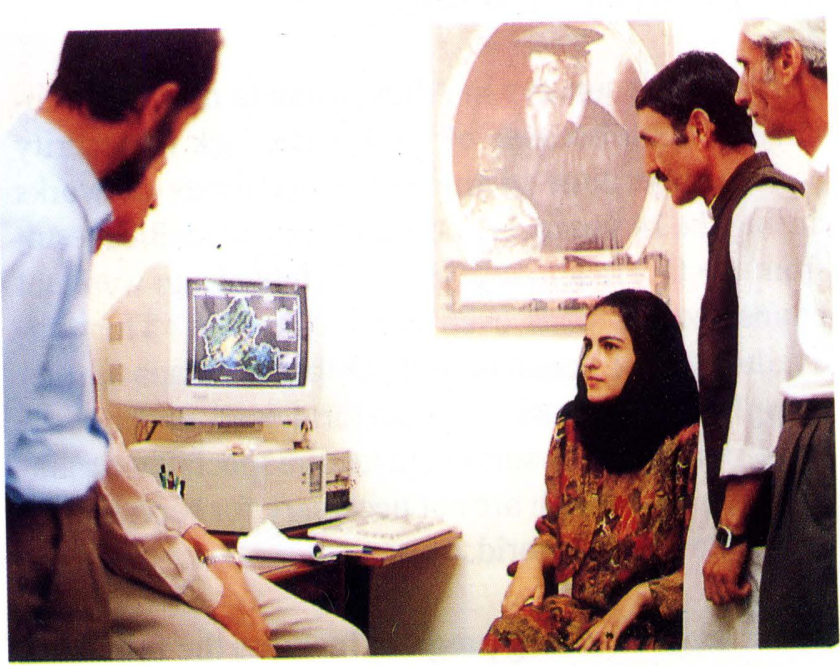

An IU staff member demonstrates computer produced maps. 


\section{MORE ON MARIS: \\ Getting Better Information on Market Prices}

To improve data reliability ASSP/PSA's market information system (MARIS) is making dramatic changes in its data collection methods. For several months project management has studied alternatives to the collection of data by interviewing travellers in Pakistan border towns. The decision has been made to collect data by direct observation in bazaars inside Afghanistan.

Already this newly designed method of collection is being tested with the assistance of ASSP/PSA extension agents working in Afghanistan. They are reporting prices for selected commodities on a monthly basis. MARIS surveyors, taking advantage of the currently improved access, are visiting bazaars in Kabul and Kandahar to collect price information.

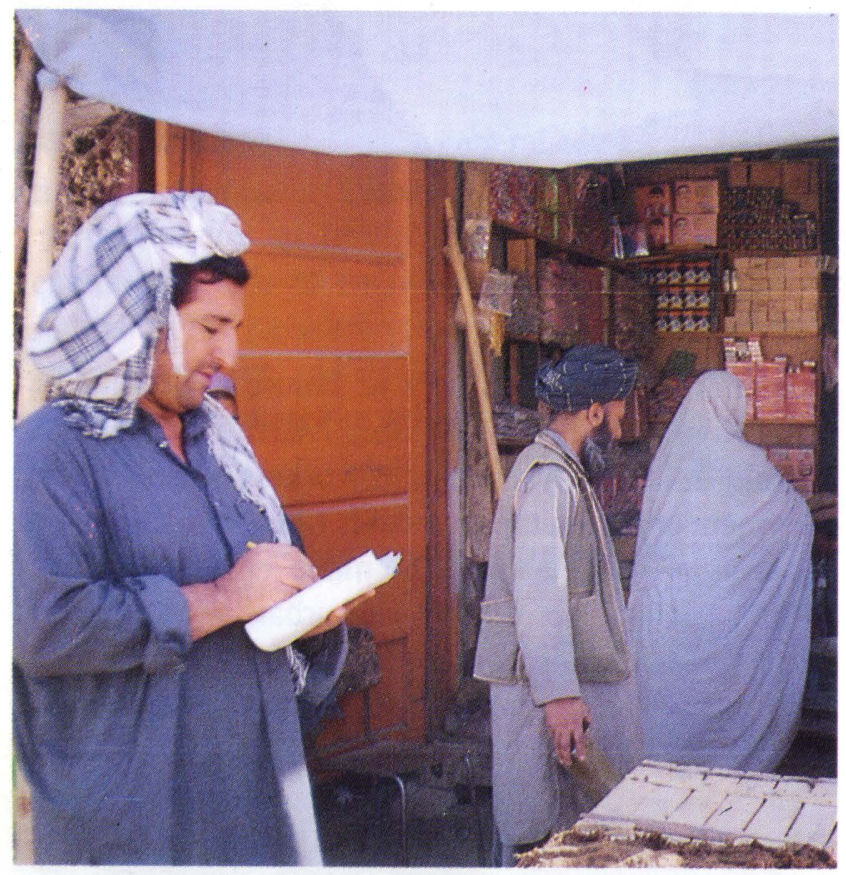

A MARIS surveyor collects price data in the Ghazni bazaar.

The MARIS price collection effort is being expanded at a particularly important time. Recent developments in Afghanistan have resulted in the virtual cessation of data collection by the Afghan government. To fill this gap and take full advantage of a proven methodology and reporting capability, major cities in twelve provinces have been selected for MARIS activities. Population, regional representation and ease of access were the basis of selection

\begin{tabular}{|ll|}
\hline & $\begin{array}{c}\text { Centers Selected for } \\
\text { MARIS Price Data Collection }\end{array}$ \\
\hline Province & City Market Centers \\
\hline Kabul & Kabul(2) \\
Nangarhar & Jalalabad(2) \\
Herat & Herat(2) \\
Ghazni & Ghazni \\
Kandahar & Kandahar (2) \\
Balkh & Mazar-i-Sharif(2) \\
Helmand & Lashkargah \\
Parwan & Charikar \\
Paktya & Gardez \\
Baghlan & Baghlan \\
Samangan & Aybak \\
Logar & Kulangar \\
Kunduz & Kunduz \\
\hline
\end{tabular}

Beginning in October, if security conditions permit, MARIS surveyors will travel twice monthly to the selected centers to collect price data. They will identify shopkeepers who will be paid a retainer fee to collect weekly prices. This will enable MARIS to capture price information for an entire month without hiring additional surveyors. If this approach proves practical, MARIS surveyors will only need to visit locations once each month to collect completed forms and verify information.

The Commodity Price Bulletin currently reports monthly wheat and fertilizer prices as well as changing exchange rates. An expanded format now being developed will provide quarterly reports of routinely collected prices of about 30 other commodities.

Organizations interested in receiving the Commodity Price Bulletin should contact the Director of Publications, ASSP/PSA. Persons interested in working with the market data set which goes back to 1988 should contact ASSP/PSA's Director of Agricultural Statistics. $\square$ 


\section{PROSPECTS for MANPOWER TRAINING in AFGHANISTAN:}

Dr. Khairullah Dawlaty, Senior Economist with ASSP/PSA, has contributed the following analysis of the needs for agricultural training in Afghanistan. He was until recently a professor and head of the Department of Agriculture Economics and Extension, Faculty of Agriculture, Kabul University. He is a graduate of Kabul University and holds a master's degree from the University of Wyoming and a doctorate in Agricultural Economics from the University of Tennessee, USA.

For any national development endeavor, no single resource is more important than the minds of the people. In the context of the present age of science and technology, manpower means "brain power". It is regarded as the most valuable investment capital of every nation.

In modern economics, human resource development is regarded as part of the production function. By itself, it can change the total output of goods and services without any change in the amount of labor.

Along with nutrition, health, recreation and cultural needs, training is a crucial element in the process of manpower development. Through training the level of knowledge is expanded and an individual's ability is adjusted to take advantage of advances in science and technology.

For adopting new technologies, for boosting food production, for operating firms and factories, for trading in the diverse world markets, for unifying peoples and tribes into a single national unity, for establishing a state based upon human rights and democracy, and finally, for preserving religion, culture, art and literature, there is one required precondition. That precondition is the education and training of the people.

Balancing the manpower training needs with the existing structural and technological framework of an economy is a matter of basic policy in the manpower planning agenda. Training and the development of skills should match the available opportunities to work. The supply of capital equipment, demand for skilled labor, and demand for goods must fit the supply of manpower with specifically adaptable skills and knowledge.

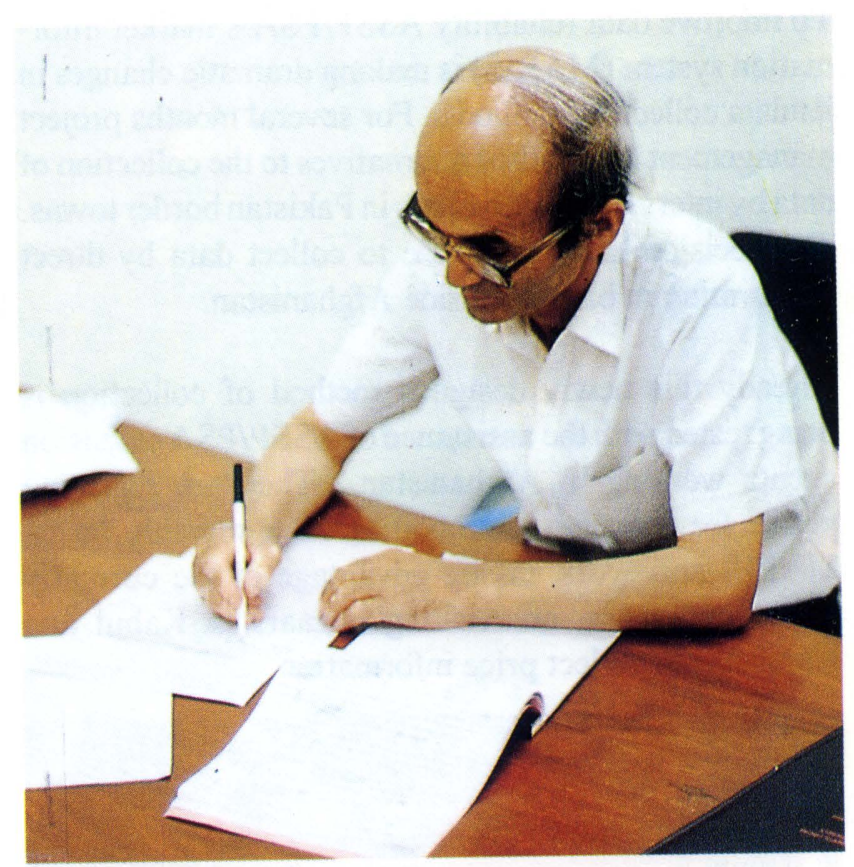

Dr. Khairullah Dawlaty is caught in a typical pose.

Deviation from this balance or failure to provide adequate living conditions and incentives can spell disaster. "Brain-drain"' may result or, if workers remain, unemployment or underemployment is likely to follow. The result may be a labor force made up of masses of illiterate, unproductive, rural and urban workers caught in the trap of unemployment and the lack of opportunities to understand the language necessary for the adoption of new technologies.

\section{Manpower Training in Afghanistan}

Any plan for manpower training in Afghanistan either within the scope of specialized, narrowly targeted programs or in broad national planning activities must treat the wounds of war on the educational system as a first step.

Actions should be specified to achieve short and long term goals for the modernization of training relative to the self-reliance and sustainability of domestic agricultural, industrial and service production needs of the country. Based upon this reasoning, an agenda is offered for agricultural training in Afghanistan: 


\section{A. Short Term Training Needs and Actions}

Restoration of the vocational training system, including agricultural and technical schools, requires immediate attention. Emphasis needs to be placed on curriculum and teaching programs responsive to agricultural production and economic development in Afghanistan.

Rapid rehabilitation of Afghanistan's agricultural extension system will promote desirable changes in knowledge, skill and attitudes of farmers as well as achieving a service institution intermediate between innovative research and agricultural production.

Many teachers were lost during the war years. Reassembling a teaching staff with the necessary agricultural training competency is as critical as restoration of the system. Practical and experimental laboratory training is considered an important component of the training process.

Planning and implementing general education and special training programs takes time and the process absorbs a large number of trained people to teach the new generation. It is to be noted that general education establishes the base for vocational, technical and professional training. As a source for supplying teachers, strengthening teacher training institutions in both quantity and quality is another immediate task.

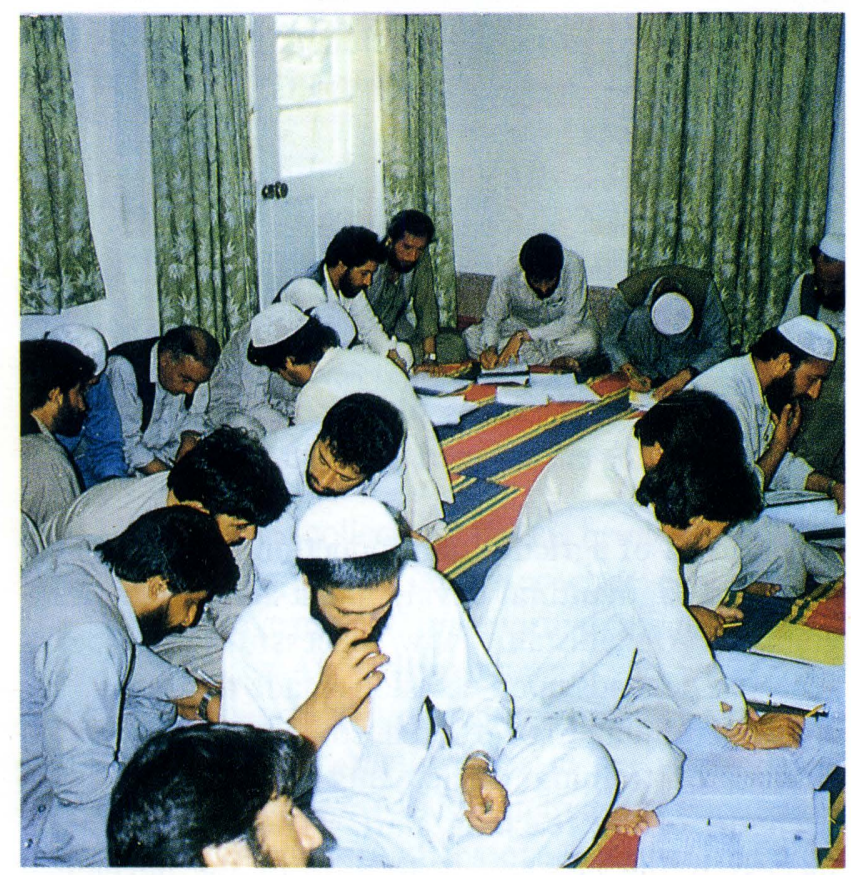

ASSP extension agents study their training notes.
Allied to the building of teacher training programs is the need for developing agricultural research centers to put Afghanistan back into the main stream of modern technology.

The curricula of the schools (vocational and general) and higher training institutions have been destroyed or distorted by the reforms imposed erratically by occupation policies. Restoring and readjusting curricula to meet current national agricultural and industrial needs is another area for immediate attention.

Early implementation of special skill-oriented training programs for young "Mujahideen" who have returned, or are returning to their home provinces with their families as repatriated refugees, is an important national training need. These men are vast in number and all are above the usual school age. They need to be merged into the normal manual and professional employment structure of the economy quickly rather than be recruited as factional soldiers and fighters.

Another national need is the reconstruction of the physical infrastructure of the formal education system which has been destroyed or damaged beyond usefulness. Buildings, teaching materials and all accessories need rehabilitation or replacement.

\section{B. Long Term Training Needs and Actions:}

Broad based general literacy programs are necessary in the long term to help eliminate existing social barriers and promote greater national unity among Afghans. Present barriers seriously impede the modernization of agriculture and economic development. Farmers need a basic level of literacy in order to grasp knowledge of new agricultural practices and innovative technologies. Farmers need to be trained for local leadership roles, and farm/home extension programs, such as those which have been successful in Southeast and East Asian countries, need to be developed.

A top priority is balancing training needs at all levels and the development of local capabilities with the existing structure of the economy.

From the standpoint of expenditure of funds on training, two important points should be noted: (1.) As is typical in a developing country, a significant proportion of the population of Afghanistan is in the dependent age group and in need of training and basic education; and 


\section{PROSPECTS for MANPOWER TRAINING continued...}

(2.) economically, the country is standing at a rock bottom poverty level with no economic surplus or reserve for supporting any extraordinary mass educational training programs. Relative to these constraints, answers to the following questions are crucial to planning manpower training programs in Afghanistan:

How much training is required?

What kind and quality of training is needed?

How should training opportunities be allocated?

Keeping these questions in mind, the following points should be considered in the long term planning of manpower training programs in Afghanistan:

1. Training in agriculture should not take place in isolation. Agricultural training expenditure should be parallel to expenditures on new agricultural inputs and technologies, improvement of markets, transportation and resource utilization.

2. Vocational, agricultural and technical training should be oriented toward employment opportunities in both the public and private sectors.

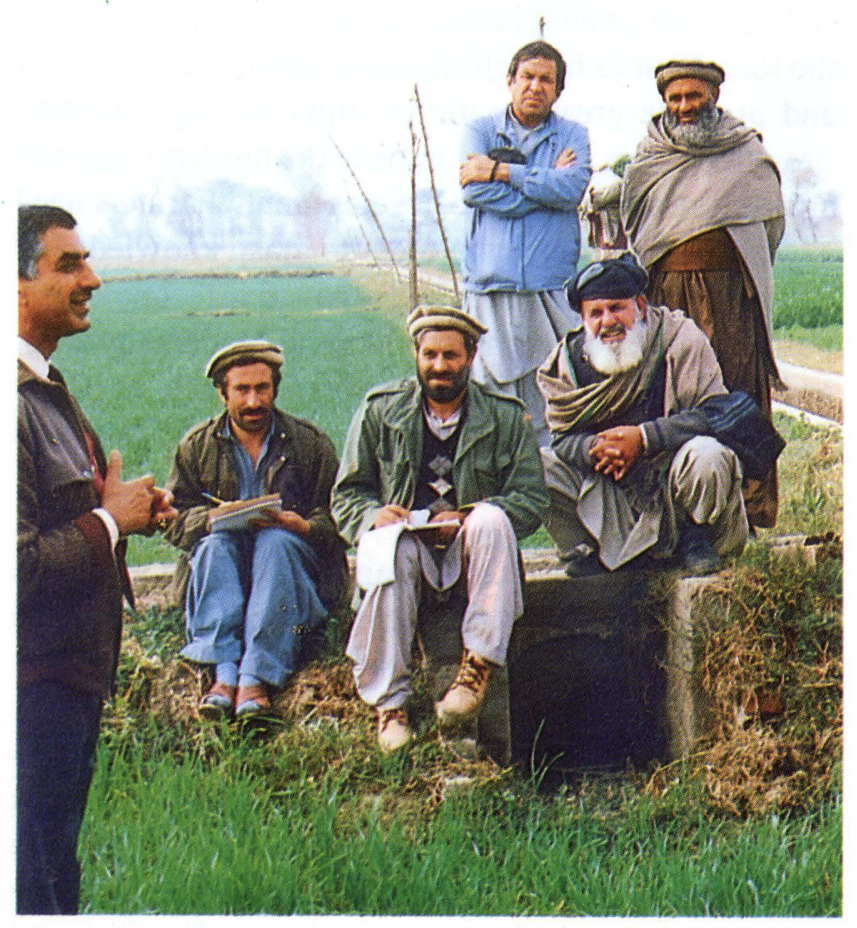

ADT instructors teach in the fields

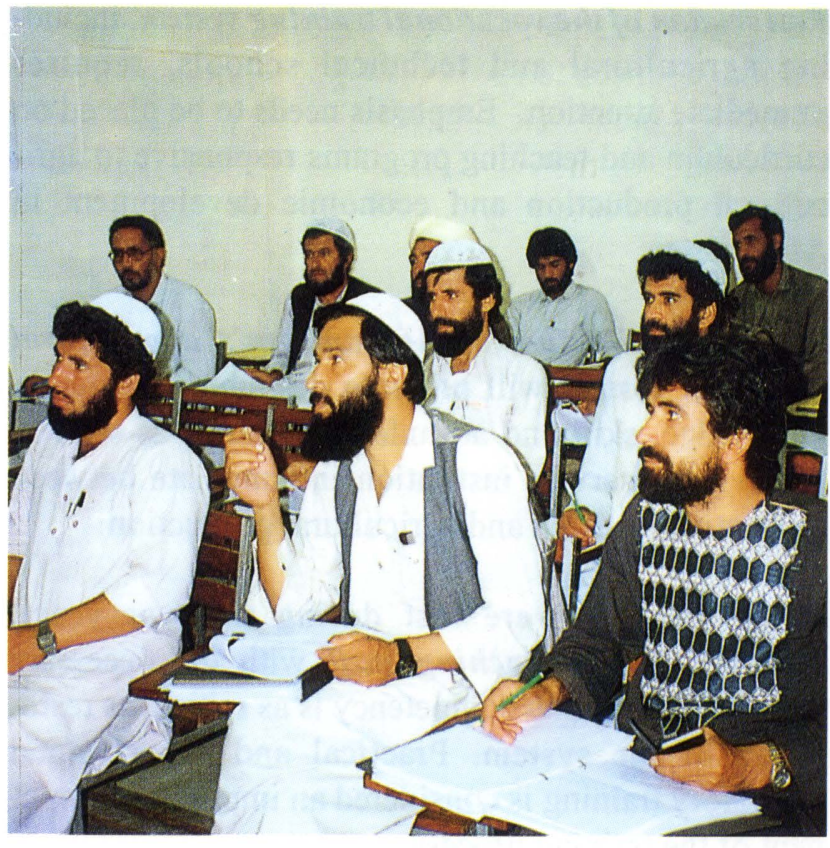

... and in more traditional classrooms.

Attention should be given to higher pay, status recognition and improvement in the work/ living environment of agricultural workers.

3. Training should be an intrinsic part of any rural development project and rely upon community participation with a minimum of or no direct dependence on the central government budget.

4. Training should be included in all foreign aid financed agricultural projects.

5. Foreign assistance in agricultural training must be tuned to local conditions and local problems. Local staff should be employed whenever and where ever possible.

6. If training takes place abroad, participants must be encouraged to return to work at home.

The growth of agricultural production is the ultimate goal of all agricultural development and training programs in Afghanistan. How successfully the goal is achieved depends upon decisions made first about: the levels of training to be offered, subjects to be covered, number of training participants and the necessary strengths of the teaching staff. The final factor in success is the efficient utilization of the developed manpower. $\square$ 


\section{APRICOTS: Another Dried Fruit for Afghanistan}

Last month Leighton Smith, in a guest column, expressed the need to revitalize the grape/raisin industry in Afghanistan. This month attention is directed to work done in the field of apricot drying by another ASSP/PSA consultant. Michael Tsamparlis, High Value Horticulture, Plc., spent a busy three weeks in June, 1992 working in Pakistan.

Dr. Tsamparlis taught by lecture and demonstration a practical technique for drying apricots; developed the curriculum for a future course and, after making a brief market analysis, made recommendations for the future of the apricot drying industry in Afghanistan. About 28 ASSP/PSA extension workers, farmers, businessmen and representatives from 14 other organizations concerned with horticulture in Afghanistan participated in the course.

The report of Dr. Tsamparlis' work, now added to the ASSP/PSA Publications List (Please see pages 13 and 14 for the full list and ordering information.), is a very enthusiastic blend of scientific information and downhome practical advice.

The goals of the initial course were not just to produce high quality dried apricots, but to stimulate interest in the profit making possibilities of dried apricots from Afghanistan. Some of the course participants were Pakistani fruit processors and dried fruit buyers.

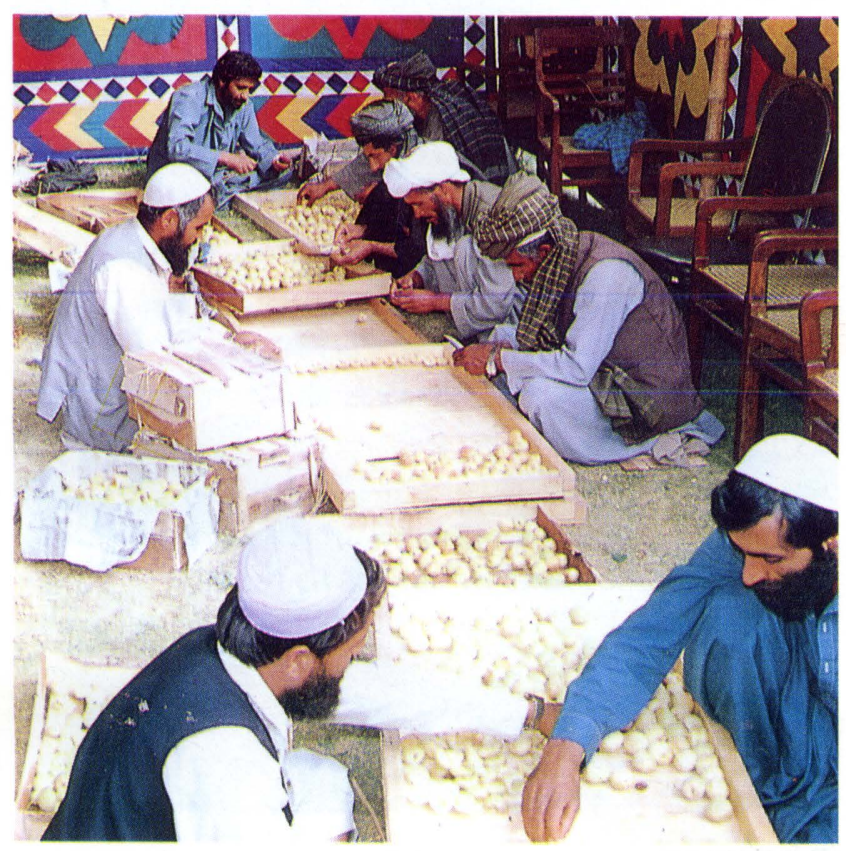

Apricots are sorted before sulphuring and drying.

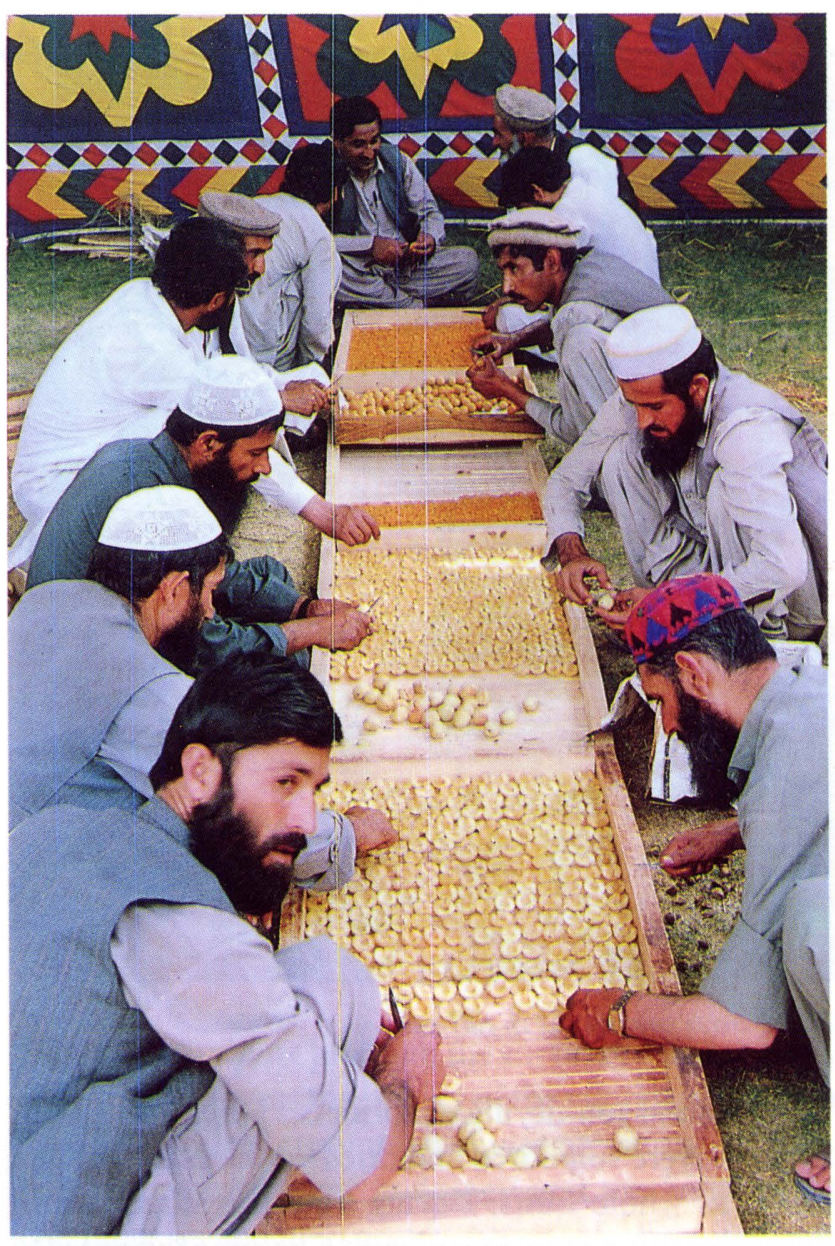

Apricots are cut and placed carefully on trays.

Dr. Tsamparlis vividly describes the pleasant classroom under a shamayana (brightly colored canopy) in Quetta and the unfortunate placement of drying tables close to a busy highway where dust rose and fell on the drying apricots. He notes that "Although nothing could be done to improve the overall situation (traffic on the highway), some action was taken concerning the ants (which attacked the drying fruits)."'!

After he gets past the need to make alterations in the sulphuring chamber, reorient the drying racks and help the "students" to accept the surprising fact that fruit on the drying racks must be turned every morning at six o'clock during the drying period, Dr. Tsamparlis makes the satisfying discovery that "the quality of the final product was excellent... would have no difficulty in European markets"'.

Repeatedly, Dr. Tsamparlis emphasizes the need for quality control, care and cleanliness in the selection, 


\section{APRICOTS continued...}

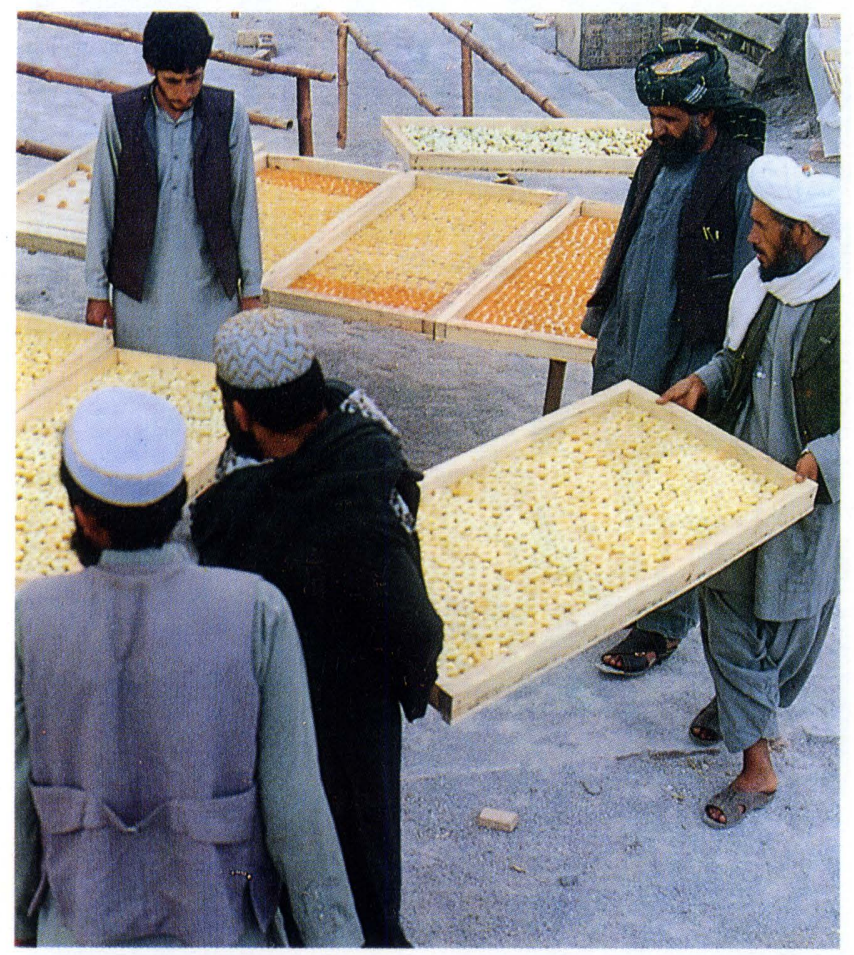

Filled trays are placed in full sun.

handling and sun-drying of apricots. Three varieties of apricots were sulphured and dried, some as halves and others as whole fruits. Drying time was three to four days regardless of variety or cut. Charmaghz proved to be the Afghan variety of apricot which consistently resulted in a high quality dried product. It also happens to be a variety not produced by the already strong leaders in the international dried apricot market.

A quality dried product requires a quality fresh product. According to Dr. Tsamparlis, the quality of a fresh apricot is determined initially by its lack of bruises and hail spots, its ripeness and its size. How the fruit is picked and packed for immediate use, sale, storage or shipment further influences its quality.

Sulphuring is the only technical operation in the apricot drying cycle. It helps to prolong the shelf life of the dried fruit and fix the attractive yellow color. Typically the fruit to be dried is exposed to sulphur dioxide gas in a drying chamber. Alternatively, the fruit may be dipped in a solution containing sulphur. Because sulphuring partially sterilizes dried fruits, the process is strongly recommended in Afghanistan today despite the current international appeal of naturally dried products.
In addition to the stress he places upon cleanliness and quality control, Dr. Tsamparlis strongly recommends one specific change in the traditional Afghan process of sulphuring and sun drying apricots - or any other dried fruits. He advocates investment in mechanical dryers for use in at least part of the drying process because, in a mechanical dryer, the drying conditions may be controlled and the product is sterilized by the high temperatures used. Sterilization makes the product more acceptable in the world market.

In his market analysis, which tracks the fresh apricot from producer to orchard owner to wholesaler to retailer, Dr. Tsamparlis reveals a "huge" profit for the wholesaler and a minimum profit (incentive) for the producer to improve the quality of his fresh fruits. To better distribute the profits as well as to produce more quality fruits, he recommends that drying be done by the producers, individually or collectively.

Dr. Tsamparlis' report is well illustrated with pictures of the many stages of the apricot drying process. In the appendices he also includes detailed instructions for the construction of a drying tray and a sulphuring chamber. His final entry is an exhaustive checklist and report form to be completed by anyone monitoring fresh and dried apricot production. $\square$

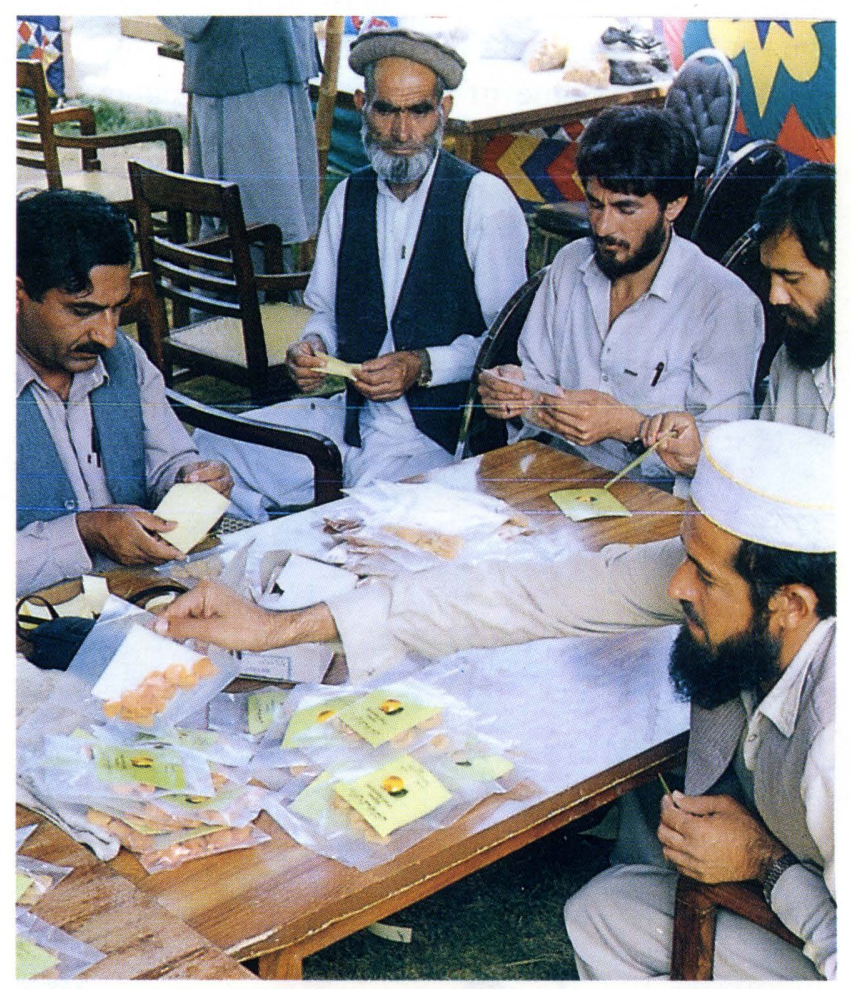

Dried apricots are again checked for quality and then packaged for sale. 


\section{TRAINING in INFORMATION MANAGEMENT: Technology Transfer for the Future}

During the past three years ASSP/PSA has provided Afghan and Pakistani staff with short courses and onthe-job training in many aspects of information management. The focus has progressed from development of the basic skills required for computerized data entry to emphasis on data maintenance and, finally, to the art of data manipulation for analysis and display.

Technical assistance in carrying out this training has come from several sources. The DAI home office has sent staff and consultants to Islamabad for short periods of time. Of critical importance to the success of the program has been the expertise contributed on site by the ASSP/PSA subcontractors, Earthsat and GIC. Several members of the project staff have attended short courses in the US.

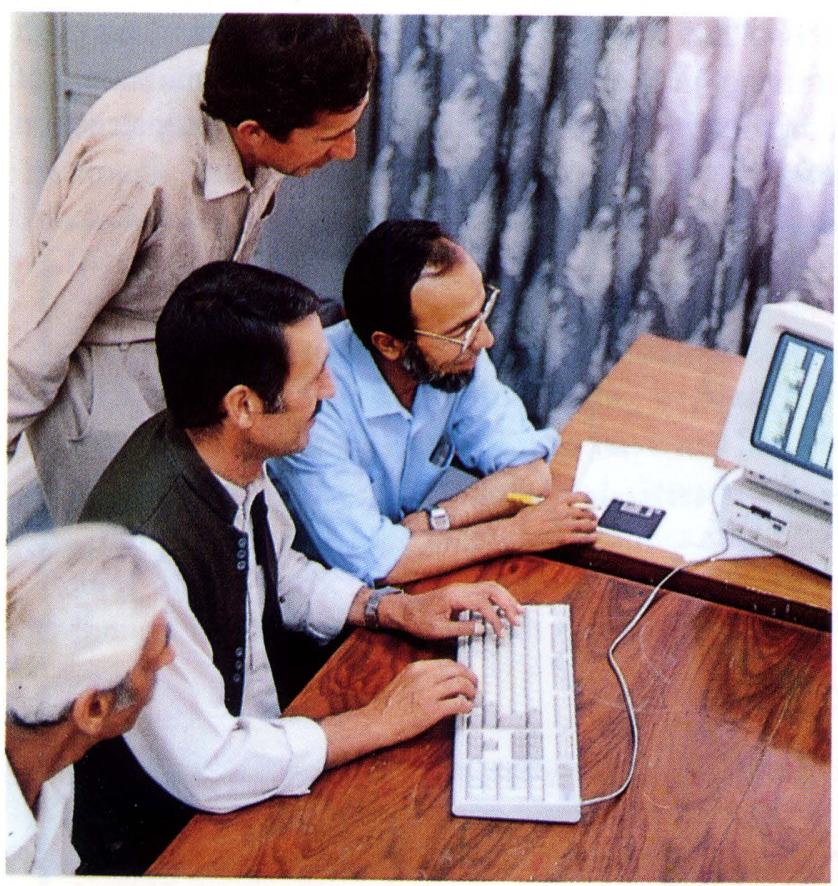

The visiting Afghan team of professionals practices with ASSP/PSA's high tech software.

This autumn a new dimension has been added to assure the management, operation and maintenance of the computer based information systems now in Islamabad and, in the future, in Afghanistan. ASSP/PSA is fortunate to have as apprentices for a few months a small group of Afghans already familiar with the collection and interpretation of spatial data concerning Afghanistan's land use, agriculture and natural resources. Integrating these professionals with ASSP/
PSA staff with their gQod command of the most recent computer hardware and software results in a lively exchange of knowledge.

One of the visiting Afghans is a specialist in cadastral surveying to determine land use and ownership. He has studied and worked in the American West as well as in Kabul. Other members of this group have studied under the aegis of the United Nations in Poland, Tajikistan and India. One of them works with cadastral surveys and computerized data gathered by astronomers. One member of the visiting team is an astronomer. He fixes locations by first order triangulation with the stars and has visited Algeria to compare observatories there with those in Afghanistan. Yet another of these professionals has worked for many years in field surveying. He now adds data collected by remote sensing, aerial photography and satellite imagery to his topographic maps.

To assure the best possible transfer of technology, a series of short courses, workshops and seminars have been organized for the visiting Afghans. Basic training in English as a Second Language (ESL) is provided for those who require it for better command of the language of technical applications. Computer training includes introduction to DOS, fundamentals of personal computers, typing and keyboard layout, introduction to database and electronic spreadsheet software, and, ultimately, leads to training in the geographic information system (GIS).

Other courses deal with two primary data sources: conventional ground based surveying, and remote sensing utilizing aerial photography and satellite imagery. Stress will be placed upon the potentials of each data source and the synergistic effect when they are used together. Actual imagery and survey data collected from Afghanistan by ASSP/PSA staff will be used in these courses.

Whenever possible courses will be conducted by ASSP/ PSA staff or other experts from the local community. Other resources which may be tapped include: Dr. Barry Haack, ASSP/PSA's remote sensing advisor, Earthsat and the International Center for Integrated Mountain Development (ICIMOD), Nepal. 
Six new reports are now available. These are in English and prepared by consultants employed by ASSP/PSA to work with the Agricultural Development and Training (ADT) component during the first six months of 1992.

Assessment of Wheat Production in Afghanistan by Eugene E. Saari, International Maize and Wheat Improvement Center (CIMMYT), cites observations made during his consultancy in January and subsequent recommendations.

Potato Production in Afghanistan, prepared in February by Garry Robertson, formerly with the Pakistan/ Swiss Potato Development Project, covers the current status of potato production, a strategy for improvement, and a detailed description of improved methods of potato cultivation.

Vegetable Program prepared in March by David B. Parsons, High Value Horticulture, Plc. (HVH), describes the training of field staff, the preparation of training materials and the implementation of the vegetable dem- onstration program. A section on integrated pest management may be of particular interest.

Fruit Program by Jim Cartwright, HVH, was also written in March. It reviews ASSP/PSA fruit tree nurseries and demonstration orchards in Darragh and Swat as well as the preparation of materials for training extension agents, nurserymen and supervisors.

Viticulture Raisin Program by Leighton Smith, HVH, provides an historical background for the grape/raisin industry in Afghanistan, drafts of training materials for grape growers and raisin packers and recommendations for revitalization of the important export industry. (Please see his column in Agricultural Developments in Afghanistan, July/August 1992.)

Apricot Program by Michael Tsamparlis, a third HVH consultant who worked with ADT in June, deals with training in the production, drying and marketing of apricots. Included are instructions for the construction of drying trays and sulphuring chambers.

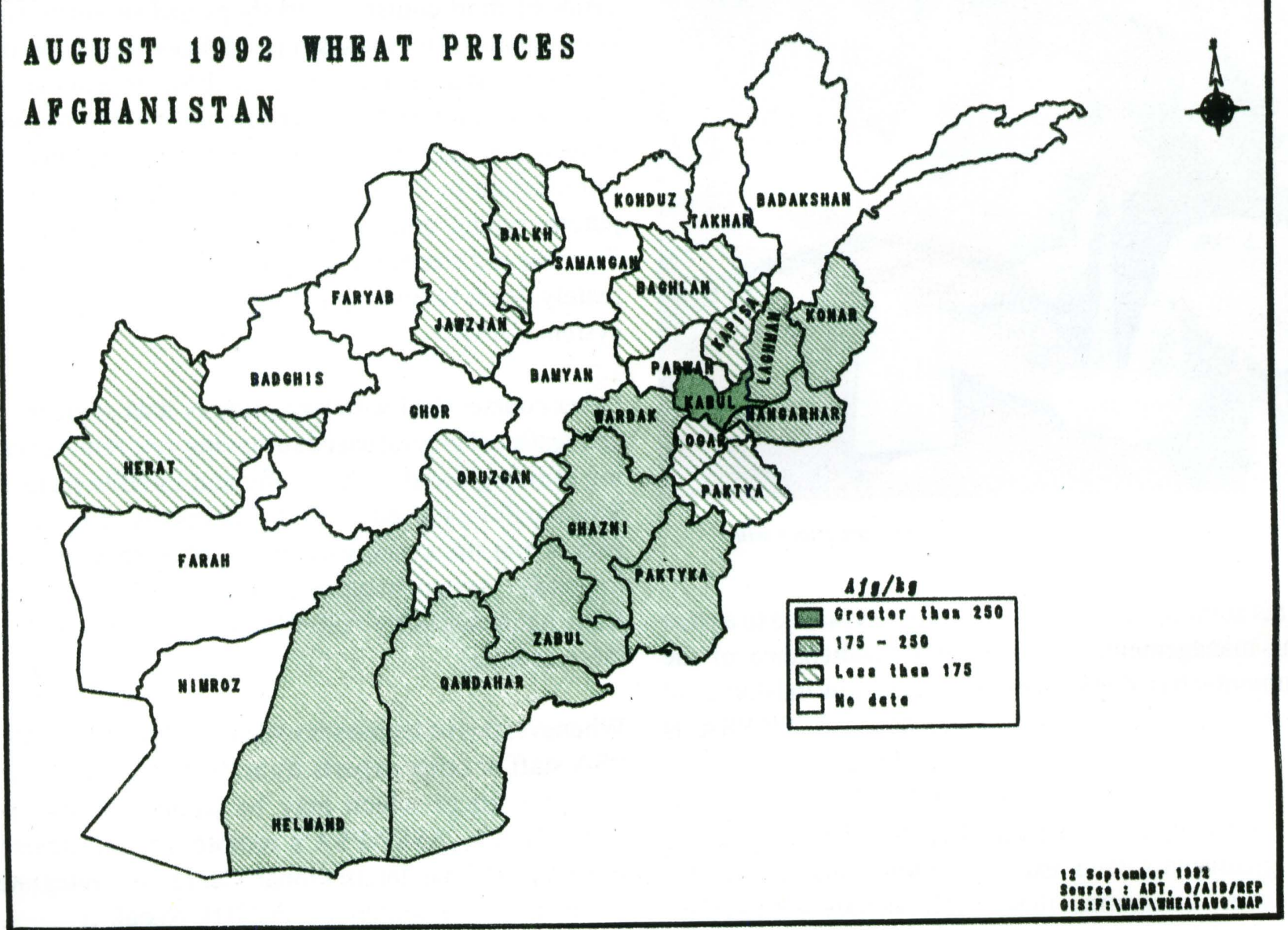




\section{ASSP/PSA PUBLICATIONS}

The following free publications about Afghan agriculture may be obtained by checking the appropriate box, cutting the page and mailing to: Director of Publications, ASSP/PSA, P.O.Box 2721, Islamabad, Pakistan.

\section{NEW REPORTS BY ASSP/PSA CONSULTANTS}

Assessment of Wheat Production, Eugene E. Saari, Jan. 1992

D Potato Production, Garry Robertson, Feb. 1992

口 Vegetable Program, David B. Parsons, Mar. 1992

a Fruit Program, Jim Cartwright, Mar. 1992

口 Viticulture Raisin Program, Leighton Smith, May 1992

a Apricot Program, Michael Tsamparlis, June 1992

\section{PUBLICATIONS IN DARI}

No. 1. Growing Corn in Afghanistan, Peshawar, 1991

$\square$ No. 2. Growing Potato in Afghanistan, Peshawar, 1991

$\square$ No. 3. Safe use of Pesticides, Peshawar, 1992

口 Trainers' Manual, Training Program for Pesticide Users, Peshawar, 1992 [originally prepared and printed in 1985 by the Consortium for International Crop Protection (CICP) and the United States Agency for International Development (USAID)]

\section{EXTENSION}

Animal Husbandry Program 1991, April, 1991

A Assistance to Afghanistan in the Livestock Subsector, December, 1989

High Value Horticulture: Cash Crop Feasibility Study, September, 1990

Agroforestry in Afghanistan, October, 1990

| Pilot Locust and Senn Pest Control Project for Afghanistan in Badghis Province, September, 1990

1 Wheat Production in Afghanistan: An Assessment of Potentials and Problems, March, 1990

a Afghanistan Crop Potential Series: Bulletin No. 1: Maize

a Afghanistan Crop Potential Series: Bulletin No. 2: Grapes and Raisins

a Afghanistan Crop Potential Series: Bulletin No. 3: Apricots

口 Afghanistan Crop Potential Series: Bulletin No. 4: Apples

a Afghanistan Crop Potential Series: Bulletin No. 5: Pomegranates

口 Afghanistan Crop Potential Series: Bulletin No. 6: Licorice

a Afghanistan Crop Potential Series: Bulletin No. 7: White Cumin

a Afghanistan Crop Potential Series: Bulletin No. 8: Citrus

口 Afghanistan Crop Potential Series: Bulletin No. 9: Barley

口 Afghanistan Crop Potential Series: Bulletin No. 10: Potatoes

\section{MARKET INFORMATION}

Exchange Rate Trends and Volatility, Market Information Occasional Paper Series No.2, January, 1992

The Rapidly Changing Picture of Afghanistan Agriculture, Market Information Occasional Paper Series No. 1, September, 1991

I Changes in Fertilizer and Wheat Prices; Afghanistan and Selected Provinces, 1990-1991 October 1991

I Commodity Price Report April-June 1991, October, 1991

I Commodity Price Report January-March 1991, June, 1991

I Commodity Price Report October-December 1990, May 1991

| Commodity Price Report July-September 1990, October , 1990

Agricultural Price and Exchange Rates in Afghanistan, 1988 to 1990, August 1990 


\section{PUBLICATIONS continued...}

An Overview of the Market Information Requirements of the Agricultural Sector Support Project, June, 1990

\section{SURVEYS AND TRIP REPORTS}

Survey VI : Agricultural Resource Inventory, Saidabad, Wardak Province, May 1991

口 Survey V : Agricultural Practices in Shah Joi, Zabul Province, April 1991

Report on Findings of Bazaar Survey IV, October 1990

口 Survey III : A Preliminary Analysis of Border Catchment Points and Their Role in Cross-Border Trade between Afghanistan and Pakistan, August 1990

口 Report on Findings of Bazaar Survey II, May 1990

Report on Findings of Bazaar Survey I, April 1990

口 Trip Report Bamyan and Parwan Provinces; A Report on Bazaars, August, 1990

C Report on Ground Truthing Mission to Afghanistan, April-May 1991

\section{PRIVATE SECTOR AGRIBUSINESS}

- Illustration of Project Impact on Afghanistan Agriculture, 1989-91, October 1991

The Prospects for Officially Sanctioned Private Sector Participation in Pak- Afghan Ferilizer and Machinery Trade and Transport, May 1991

口 Farm Machinery, October, 1990

口 Private Sector Agribusiness Support, September 1990

G Financing Cross-Border Trade: Reconstructing Agriculture and Agribusiness in Afghanistan, September 1990

․ Private Sector Agribusiness Support, September, 1990

Restraints and Possible Interventions to Increase Agricultural Inputs to and Outputs from Afghanistan, August, 1990

Recommendations on Farm Machinery for Use in Afghanistan, August, 1991

\section{SILK SCREEN POSTERS}

The silk screen posters created by Aminullah Baqizad, a member of the ASSP staff, are available in limited numbers. They measure about one meter square. All script is in Pashto and Dari. Subjects of the posters are:

1. Growing rice by rows ( pictured in Feb. 1992 issue of Agricultural Developments in Afghanistan).

2. Growing potato in rows.

3. Comparing local and improved varieties of wheat .

4. Comparing new and old methods of harvesting wheat .

5. Comparing new and old methods of threshing wheat.

6. Growing maize in rows. 